\title{
ORGANIC VS CONVENTIONAL ALMOND: MARKET QUALITY, FATTY ACID COMPOSITION AND VOLATILE AROMA COMPOUNDS
}

\author{
KARAAT, F. E. \\ Adlyaman University, Faculty of Agricultural Sciences and Technologies \\ Department of Plant Protection, 02040 Adlyaman, Turkey \\ e-mail:fkaraat@adiyaman.edu.tr \\ (Received 17 $7^{\text {th }}$ Mar 2019; accepted $3^{\text {rd }}$ May 2019)
}

\begin{abstract}
Organic agriculture is an integrated form of agriculture combines techniques of ancient knowledge with current science and targets to exclude inorganic fertilizers, growth regulators and pesticides. Generally organic products are accepted as healthier and better tasting. This opinion is more common for fruits and vegetables. Series of studies on comparison of organic and conventional fruits and vegetables have been performed but comparison of analytical quality parameters lacks in previous studies especially fatty acids and volatile aroma compounds. This study compares pomological parameters, some selected chemical properties, fatty acid composition and volatile aroma compounds of organic and conventionally grown Ferragnes and Ferraduel almond cultivars. Results indicated significant differences between cultivars and growing systems suggesting a better overall market quality for organic kernel samples. Total oil and linoleic acid was lower in organic samples, whereas oleic was higher $(82.4 \%$ in both cultivars) when compared with conventional samples $(78.9 \%$ for Ferragnes and $75.8 \%$ for Ferraduel). Most of the aroma compounds detected in this present study are new record for almond aroma-active compounds. In an overall view, organic samples resulted with higher contents of aroma compounds.
\end{abstract}

Keywords: composition, kernel, quality, Prunus amygdalus, taste

\section{Introduction}

The most widely cultivated nut crop of Mediterranean area is the almond. World almond production was more than two tons, and The United States was the leading producing country (1.029.655 tons) followed by Spain (255.503 tons) and Turkey was the fifth country with the production of 90 thousand tons (FAO, 2019). Almond growing areas have significantly increased in last decades, and this increase is due to increasing demand for almond thanks to its natural and healthy food ingredients. Many reports have been published on nuts as a beneficial food source for human consumption, and considered as an essential balancing component in diets especially because of rich nutritional value. Even though almond contents high amount of fat, it has high amounts of unsaturated fatty acids (both mono and poly) and fiber (Sánchez-Bel et al., 2008).

Main quality aspects of almonds are their chemical composition, fatty acids composition, aroma compounds, protein and ash content, etc. Varying mainly depending on genetic background and ecological factors, but also cultural practices, general chemical composition of an almond is fat, proteins and carbohydrates in the percentages of 50-60, 20-25 and 20, respectively (Sánchez-Bel et al., 2008).

Today, agricultural practices are designed by knowledge of intense research, and especially studies on organic agriculture including organic fertilization have strong effects on the capacity of food production. Therefore, many studies have been performed to observe the increase in yield and quality of the almond in ecological agriculture and organic fertilization (Heeb et al., 2006; Lester et al., 2007; Sánchez-Bel 
et al., 2008). Organic farming benefits biodiversity (Bengtsson et al., 2005; Hole et al., 2005), and have the potential of increasing yield in some cases, especially with better water use efficiency and less carbon sequestration and pesticide use (Pretty et al., 2006; Wood et al., 2006). On the other hand, organic growing has the disadvantages of higher input and lower yield for the farmers (Guichard et al., 2001). In terms of consumer acceptance, organic foods are better welcomed, since consumers assume organic crops as higher quality (better tasting and more nutritious) rather than those conventionally grown crops (Ekelund and Tjarnemo, 2004; Gąstoł et al., 2011). Indeed, there are various reports on health benefits of organic crops (Lester et al., 2007). For that reason, organic crops growers ask higher prices for their crops to balance the relevant disadvantages. However, this demand of the growers is generally met by displeasure of traders and consumers.

Previously, some comparison studies about organic and conventional almond were published. Venkatasubramanian (2011) conducted a retail level study and compared some nutritional quality aspects of organic and conventional market foods including almond snacks. Sánchez-Bel et al. (2008) compared organic and inorganic fertilizers on potted almond trees, cv. Guara. A profitability comparison study was performed for organic and conventional almond orchards (Anonymous, 2011). On the other hand, a number of studies compared organic and conventional fruits based on sensory tests (Bourn and Prescott, 2002). But, previous studies about comparison of organic and conventional grown almond fruit quality are limited, especially for fatty acid composition and volatile aroma compounds.

In the previous studies, generally two methods of investigating differences between organic and conventional products have been applied which are cultivation and retail market studies. Both of them are focused on advantages and disadvantages. The approach used in this study is the compositional analysis of crops obtained from farm and cultivation rather than purchasing products from market. Farm and cultivation studies differ from retail market studies with the information available on cultivar, environmental conditions, harvest and post-harvest influences etc. Therefore, retail studies are reported as representative of the growing system in broad sense (Magkos et al., 2006).

For all of those reasons, in order to evaluate flavor related aroma compounds and various quality aspects of organic and conventional growing in almond this study was conducted to compare final quality of almonds grown organic and conventionally.

\section{Materials and Methods}

The study was conducted in Konuklu Village located in Besni County of Adiyaman Province, Turkey $\left(37^{\circ} 36^{\prime} 11.13^{\prime} \mathrm{N}\right.$ and $\left.37^{\circ} 56^{\prime} 00.15^{\prime} \mathrm{E}\right)$ in 2018 which was a normal year in terms of climatic conditions for the area (Table 1). Plant materials of the study consisted of 8 years old organic and conventionally grown trees of Ferragnes and Ferraduel cultivars grafted on wild almond (Prunus amygdalus var. amara). Organic and conventional trees were grown in two nearby orchards that eliminate climatic influences. Pest management, weed control and soil cultivation were done as required. Drip irrigation and fertigation were utilized, and no nutrient deficiencies and water stress were observed during the season.

The study was conducted according to randomized block design including the plantation and fruit sampling, and from each genotype representing fruit samples were 
collected as required at harvest maturity stage (Anonymous, 2014). Fruit samples were subjected to hull separation and obtained nuts were sun dried for 4 days until 7\% moisture level. Totally $10 \mathrm{~kg}$ of nuts (kernel with shell) samples were collected from each cultivar in each orchard. After two months of preservation of dried nuts at room temperature, pomological properties, chemical composition, fatty acid composition, and volatile aroma compounds of collected fruit samples were examined.

Table 1. Meteorological records of experimental area (MGM, 2019)

\begin{tabular}{c|c|c|c|c|c|c|c|c|c|c}
\hline \multirow{2}{*}{} & \multicolumn{2}{|c|}{ May } & \multicolumn{2}{c|}{ June } & \multicolumn{2}{c|}{ July } & \multicolumn{2}{c|}{ August } & \multicolumn{2}{c}{ September } \\
\cline { 2 - 10 } & $\mathbf{2 0 1 8}$ & MYA & $\mathbf{2 0 1 8}$ & MYA & $\mathbf{2 0 1 8}$ & MYA & $\mathbf{2 0 1 8}$ & MYA & $\mathbf{2 0 1 8}$ & MYA \\
\hline \multirow{2}{*}{ MT } & 19.8 & 20.6 & 24.2 & 26.8 & 28.3 & 31.1 & 28.8 & 30.6 & 25.4 & 25.8 \\
MMT & 27.1 & 26.6 & 32.0 & 33.2 & 36.4 & 37.6 & 36.6 & 37.5 & 32.8 & 33.0 \\
MNT & 12.5 & 14.3 & 16.3 & 19.7 & 20.4 & 23.7 & 21.4 & 23.4 & 17.9 & 19.0 \\
MP & 45.2 & 43.3 & 52 & 8.2 & 0.0 & 1.0 & 0.0 & 0.7 & 1.2 & 6.0 \\
\hline
\end{tabular}

MT: Mean Temperature, MMT: Maximum Temperature, MNT: Minimum Temperature, MP: Monthly Precipitation, MYA: Multi-Year-Average

\section{Pomological Evaluations and Sensory Analysis}

With this regard, nut weight (NWE), nut length (NLE), nut width (NWI), nut thickness (NTH), kernel weight (KWE), kernel length (KLE), kernel width (KWI), kernel thickness $(\mathrm{KTH})$, kernel/nut ratio $(\mathrm{K} / \mathrm{N})$, and Unit Kernel Number, number of kernels in $28.35 \mathrm{~g}$ (UKN), were measured. Nut and kernel width (mm), height (mm), and thickness $(\mathrm{mm})$ were measured using digital calipers. Nut and kernel weight $(\mathrm{g})$ were measured by precision scales $(0.1 \mathrm{~g})$, and kernel/nut ratio was calculated by division of these values. As part of market quality evaluation of the samples, consumer acceptability was also assessed by sensory analysis. For this aim, five judges (one a regular almond consumer, two almond growers, and two agriculture professionals) compared organic and conventional kernel samples in terms of their size \& shape, color, and flavor.

\section{Chemical composition}

Total oil, total protein, total ash, and moisture were detected in terms of chemical composition. Total oil content was analyzed by extraction of oil with n-hexane (60 C) for $6 \mathrm{~h}$ using Soxhlet extractor (Anonymous, 2000). Total protein content was calculated by multiplication of total $\mathrm{N}$ content which was detected according to Kjeldahl method with 6.25 (James, 1995). Total ash were determined by burning almond kernels for 24 hours at $200^{\circ} \mathrm{C}$ and 6 hours at $600^{\circ} \mathrm{C}$, respectively (Baymış, 2008). Kernel moisture content was measured according to the weight difference after heating the samples in an oven at $105^{\circ} \mathrm{C}$ for 24 hours (USDA, 1970).

\section{Fatty acid composition}

Fatty acid composition was evaluated by determination of palmitic acid, palmitoleic acid, stearic acid, oleic acid, linoleic acid contents. The fatty acid methyl esters were detected in a gas chromatograph (Shimatzu, QP2010 ULTRA) with a flame ionization 
detector and Rtx-5 MS capillary column according to Anonymous (1993). Obtained results were expressed as percentages of each fatty acid with regard to total oil content.

\section{Volatile aroma compounds}

Volatile aroma compounds were detected semi-quantitatively. Semi-quantitation (peak measurement) was done using another gas chromatograph (Agilent GC7890A) with a flame ionization detector and DB-5 ms capillary column $(60 \mathrm{~m} \times 0.320 \mathrm{~mm}$ i.d. and $1 \mu \mathrm{m}$, film thickness) and 2-methyl-3-heptanone (internal standard) was used as internal standard. Peaks were identified by comparing retention times and mass spectra of eluted compounds with those of the Wiley library (Wiley7, Nist 05, J. Wiley \& Sons Ltd., West Sussex, England).

\section{Statistical calculations}

Pomological parameters were measured in four replicates and obtained results were analyzed according to Duncan's test $(\mathrm{P} \leq 0.05)$ using SPSS 23.0 for Windows software. Data of compositional analyzes represents the average of multiple parallel measurements. Semi-quantitation was performed by comparing relative peak areas observed using FID detection, divided by the concentration in solution and compared again to that of 2-methyl-3-heptanone using headspace analysis.

\section{Results}

Fruit samples of almond trees grown organic and conventionally were evaluated in terms of pomological traits, sensorial quality, chemical, fatty acids and volatile aroma compounds composition. Pomological and sensorial evaluations were presented in Table 2 and, results of the chemical, fatty acids and volatile aroma compounds compositions were shown in Table 3, Table 4 and Table 5, respectively.

\section{Pomological Evaluations and Sensory Analysis}

Significant differences for all evaluated pomological parameters, except NLE which was not significantly differed between cultivars and growing systems. Although differences between nut and kernel sizes were significant between cultivars, they were not found significant between organic and conventional samples. NWE and KWE were significantly changed between organic and conventionally grown Ferraduel cultivar. NWE and KWE of organic Ferraduel samples were higher than conventional samples (4.9 and $4.6 \mathrm{~g}, 1.3$ and $1.2 \mathrm{~g}$, respectively). Both kernel and nut weight parameters were significantly changed between cultivars. Similarly, differences of K/N results were significant between cultivars but not between growing systems. On the other hand, UKN was significantly varied both between cultivars and between organic and conventionally grown Ferraduel cultivar. UKN of conventionally grown Ferraduel cultivar was higher than organic samples (23.8 and 21.4, respectively). Results indicated heavier nuts and kernels for organic samples of Ferraduel cultivar comparing to those conventional samples. Sensorial evaluations approved no difference between organic and conventional kernels in terms of size \& shape, but indicated that organic kernels were slightly darker and richer in flavor. Results of the pomological evaluations are presented in Table 2. 


\section{Chemical Composition}

Highest total oil content was found in conventional Ferragnes samples (46.7\%), whereas organic Ferraduel samples presented the lowest total oil content $(41.1 \%)$. Highest total protein and moisture were found in organic Ferraduel samples. The lowest values for these contents were found in conventional Ferragnes $(20.7 \%$ for total protein, and $4.5 \%$ for moisture). While ash content was not significantly varied between organic and conventional samples, in both cultivars organic kernels presented lower total oil, but higher total protein content and moisture when compared to conventional samples. Ferragnes was higher in total oil content, whereas Ferraduel was higher in total protein and moisture. Proximate chemical compositions results are presented in Table 3.

Table 2. Pomological properties of almonds at organic and conventional orchards

\begin{tabular}{cc|c|c|c|c}
\hline \multirow{2}{*}{} & & \multicolumn{2}{|c|}{ Ferragnes } & \multicolumn{2}{c}{ Ferraduel } \\
\cline { 3 - 6 } & & Organic & Conventional & Organic & Conventional \\
\hline NWE & $(\mathrm{g})$ & $4.2 \pm 0.1 \mathrm{c}$ & $4.0 \pm 0.1 \mathrm{c}$ & $4.9 \pm 0.3 \mathrm{a}$ & $4.6 \pm 0.2 \mathrm{~b}$ \\
$\mathrm{NLE}$ & $(\mathrm{mm})$ & $34.5 \pm 0.6 \mathrm{~ns}$ & $33.7 \pm 0.7 \mathrm{~ns}$ & $34.1 \pm 0.9 \mathrm{~ns}$ & $34.4 \pm 1.0 \mathrm{~ns}$ \\
$\mathrm{NWI}$ & $(\mathrm{mm})$ & $21.1 \pm 0.4 \mathrm{~b}$ & $21.6 \pm 0.4 \mathrm{~b}$ & $24.5 \pm 0.6 \mathrm{a}$ & $23.8 \pm 0.9 \mathrm{a}$ \\
$\mathrm{NTH}$ & $(\mathrm{mm})$ & $16.0 \pm 0.2 \mathrm{bc}$ & $15.6 \pm 0.2 \mathrm{c}$ & $16.5 \pm 0.4 \mathrm{a}$ & $16.2 \pm 0.4 \mathrm{ab}$ \\
$\mathrm{KWE}$ & $(\mathrm{g})$ & $1.5 \pm 0.0 \mathrm{a}$ & $1.4 \pm 0.0 \mathrm{a}$ & $1.3 \pm 0.1 \mathrm{~b}$ & $1.2 \pm 0.1 \mathrm{c}$ \\
$\mathrm{KLE}$ & $(\mathrm{mm})$ & $26.8 \pm 0.2 \mathrm{a}$ & $26.7 \pm 0.1 \mathrm{a}$ & $25.1 \pm 0.9 \mathrm{~b}$ & $24.7 \pm 0.7 \mathrm{~b}$ \\
$\mathrm{KWI}$ & $(\mathrm{mm})$ & $13.9 \pm 0.2 \mathrm{~b}$ & $14.1 \pm 0.4 \mathrm{~b}$ & $15.2 \pm 0.2 \mathrm{a}$ & $14.8 \pm 0.5 \mathrm{a}$ \\
$\mathrm{KTH}$ & $(\mathrm{mm})$ & $8.5 \pm 0.1 \mathrm{a}$ & $8.3 \pm 0.2 \mathrm{ab}$ & $8.1 \pm 0.3 \mathrm{bc}$ & $7.9 \pm 0.2 \mathrm{c}$ \\
$\mathrm{K} / \mathrm{N}$ & $(\%)$ & $35.9 \pm 1.3 \mathrm{a}$ & $35.4 \pm 1.1 \mathrm{a}$ & $26.9 \pm 0.9 \mathrm{~b}$ & $26.0 \pm 1.5 \mathrm{~b}$ \\
$\mathrm{UKN}$ & $\mathrm{Nr}$ & $19.0 \pm 0.2 \mathrm{c}$ & $20.1 \pm 0.4 \mathrm{bc}$ & $21.4 \pm 1.1 \mathrm{~b}$ & $23.8 \pm 1.6 \mathrm{a}$ \\
\hline
\end{tabular}

Differences between values signed with different letters within the rows are significant at $\mathrm{P} \leq 0.05$.

NWE: Nut Weight, NLE: Nut Length, NWI: Nut Width, NTH: Nut Thickness, KWE: Kernel Weight, KLE: Kernel Length, KWI: Kernel Width, KTH: Kernel Thickness, K/N: Kernel /Nut Ratio, UKN: Unit Kernel Number

Table 3. Proximate chemical composition of almonds at organic and conventional orchards

\begin{tabular}{c|c|c|c|c}
\hline \multirow{2}{*}{$\%$} & \multicolumn{2}{|c|}{ Ferragnes } & \multicolumn{2}{c}{ Ferraduel } \\
\cline { 2 - 5 } & Organic & Conventional & Organic & Conventional \\
\hline Total oil & 44.5 & 46.7 & 41.1 & 45.6 \\
Total protein & 20.9 & 20.7 & 21.3 & 20.8 \\
Total ash & 3.3 & 3.2 & 3.2 & 3.2 \\
Moisture & 4.7 & 4.5 & 4.8 & 4.7 \\
\hline
\end{tabular}

\section{Fatty Acid Composition}

As part of fatty acid composition, the most significant differences were found in oleic and linoleic acid contents. Oleic acid contents were higher in organic samples, whereas linoleic acid contents were lower in both cultivars. Highest oleic acid content was found in organic samples which were the same in average for both cultivars (82.4\%). Conventional Ferraduel samples were found with highest linoleic acid content 
(15.3\%) followed by conventional Ferragnes samples (12.7\%). Palmitic, palmitoleic and stearic acid contents were also higher in organic samples of both cultivars, and among the cultivars these values were higher in organic Ferraduel samples $(7.9,0.8,2.7 \%)$. Fatty acid compositions of the samples included in the study are presented in Table 4.

Table 4. Fatty acid compositions (percent) of almonds at organic and conventional orchards

\begin{tabular}{c|c|c|c|c}
\hline \multirow{2}{*}{$\%$} & \multicolumn{2}{|c|}{ Ferragnes } & \multicolumn{2}{c}{ Ferraduel } \\
\cline { 2 - 5 } & Organic & Conventional & Organic & Conventional \\
\hline Palmitic Acid (C16:0) & 6.4 & 5.9 & 7.9 & 6.0 \\
Palmitoleic Acid (C16:1) & 0.7 & 0.6 & 0.8 & 0.7 \\
Stearic Acid (C18:0) & 2.1 & 1.9 & 2.7 & 2.2 \\
Oleic Acid (C18:1) & 82.4 & 78.9 & 82.4 & 75.8 \\
Linoleic Acid (C18:2) & 8.4 & 12.7 & 6.2 & 15.3 \\
\hline
\end{tabular}

\section{Volatile Aroma Compounds}

A total of 39 volatile aroma compounds were identified in almond kernel samples included in the study. The volatile aroma compounds consisted of ketones (17), terpenes (6), alcohols (5), esters (5), alkanes (4), and aldehydes (2). When all of the volatile compounds were classified according to absence in organic or conventional samples, most of the compounds were found higher in organic samples. Indeed, overall volatile compound contents were calculated as 1519 and $1193 \mu \mathrm{g} / \mathrm{kg}$ for organic and conventional samples of Ferragnes cultivar, 1417.4 and $1325.2 \mu \mathrm{g} / \mathrm{kg}$ for organic and conventional samples of Ferraduel cultivar.

Among the detected volatile compounds Butanal, Butyl acetate, Ethylbenzene, p-Chlorotoluene, 4-Octanone were found in higher concentrations in organic samples when compared with conventional samples in both cultivars. Pentadecane, 2-methyl2-phenyl- was only detected in organic samples of both cultivars. On the other hand, some of the volatile compounds were detected in organic samples of one of the cultivar, while not found in other cultivar. 6-Hepten-3-one, 4-methyl-, 2.3-Dimethyl-1-butene, 3-Heptanone-5-methyl-, 2.6-Decadiene-4.5-diol-6-ethyl-, Decyl decanoate, Gammadecalactone were detected in organic samples of Ferragnes, but not found in conventional Ferragnes samples and both of the Ferraduel samples. Similarly, Ethanone-1-(1-methylcyclopentyl)-and m-Cymene were detected in organic samples of Ferraduel, but not found in the rest of the samples. Butyl valerate and 3-Chloropentane2.4-dione were not detected in conventional samples of Ferragnes cultivar but found in the rest of the samples.

The volatile compounds that found higher in conventional samples were butanol, 2-Methyl-3-heptanol, 2.5-Dimethyl-3-hexanone, isobutyric acid. On the other hand, 2.4-Dimethylpentane and 2-Hepten-4-one-2-methyl- were only found in conventional samples of Ferragnes, and similarly Octane-2.4.6-trimethyl-, diethyl phthalate, and gamma-undecalactone were only found in conventional samples of Ferraduel. While 3-Methyl-2-pentanone was not detected in both of the Ferragnes samples, it was detected in both organic and conventional samples of Ferraduel, and was found higher in concentration in organic samples when compared with conventional ones. Results of the volatile aroma compounds are presented in Table 5. 
Table 5. Volatile aroma compounds of almonds at organic and conventional orchards

\begin{tabular}{|c|c|c|c|c|c|}
\hline \multirow{2}{*}{$\begin{array}{c}t_{r} \\
(\mathrm{~min})\end{array}$} & \multirow{2}{*}{$\begin{array}{c}\text { Volatile aroma compounds } \\
(\mu \mathrm{g} / \mathrm{kg})\end{array}$} & \multicolumn{2}{|c|}{ Ferragnes } & \multicolumn{2}{|c|}{ Ferraduel } \\
\hline & & Organic & Conventional & Organic & Conventional \\
\hline 1.43 & Acetone & 56.0 & 23.7 & 20.3 & 23.0 \\
\hline 1.82 & Butanal & 8.8 & 2.8 & 2.2 & 1.2 \\
\hline 1.85 & 2.4-Dimethylpentane & - & 0.3 & - & - \\
\hline 1.85 & 3-Methyl-2-pentanone & - & - & 0.2 & 0.4 \\
\hline 2.42 & Butanol & 11.3 & 14.3 & 14.8 & 16.1 \\
\hline 5.39 & Butyl acetate & 31.5 & 25.0 & 24.7 & 20.1 \\
\hline 6.36 & 2-Phenyl-2-propanol & 16.2 & 5.6 & 5.5 & 6.2 \\
\hline 6.93 & Ethylbenzene & 23.8 & 19.6 & 21.6 & 18.1 \\
\hline 7.69 & 6-Hepten-3-one-4-methyl- & 5.9 & - & - & - \\
\hline 7.79 & 3-Heptanone & 7.2 & 8.2 & 9.0 & 8.7 \\
\hline 9.94 & o-Chlorotoluene & 198.6 & 159.1 & 202.4 & 211.9 \\
\hline 10.11 & p-Chlorotoluene & 91.8 & 81.2 & 171.1 & 103.0 \\
\hline 10.15 & 2.3-Dimethyl-1-butene & 6.3 & - & - & - \\
\hline 10.34 & 2-Methyl-3-heptanol & 8.4 & 17.1 & 7.9 & 13.8 \\
\hline 10.68 & 4-Octanone & 364.5 & 333.3 & 388.0 & 331.4 \\
\hline 10.93 & Octane-2.4.6-trimethyl- & - & - & - & 2.4 \\
\hline 10.93 & 2-Hepten-4-one-2-methyl- & - & 1.2 & - & - \\
\hline 10.94 & Ethanone-1-(1-methylcyclopentyl)- & - & - & 1.3 & - \\
\hline 11.12 & 3-Octanone & - & 1.9 & 3.1 & 2.1 \\
\hline 11.14 & 3-Heptanone-5-methyl- & 3.0 & - & - & - \\
\hline 11.75 & 2-Methylpentanal & 299.6 & 296.5 & 312.8 & 315.3 \\
\hline 11.97 & Pinacol & 192.5 & 91.1 & 97.5 & 108.5 \\
\hline 12.40 & m-Cymene & - & - & 6.0 & - \\
\hline 12.43 & Butyroin & 7.1 & - & - & 4.6 \\
\hline 12.53 & 2.5-Dimethyl-3-hexanone & 25.2 & 29.3 & 30.2 & 32.9 \\
\hline 12.87 & Isobutyroin & 6.7 & 5.5 & 5.9 & 7.3 \\
\hline 13.04 & Isobutyric acid & 36.2 & 39.4 & 40.7 & 44.0 \\
\hline 13.63 & Diethylbenzol & 9.3 & 9.1 & 8.6 & 11.0 \\
\hline 14.65 & Nonanone & 11.4 & 12.4 & 15.5 & 15.1 \\
\hline 14.71 & Butyl valerate & 1.3 & - & 0.7 & 0.6 \\
\hline 16.88 & Pentadecane-2-methyl-2-phenyl- & 11.1 & - & 10.4 & - \\
\hline 18.23 & 2-Methyl-1.3-dithiane & 7.0 & 6.3 & 7.2 & 7.8 \\
\hline 18.29 & 3-Chloropentane-2.4-dione & 1.8 & - & 2.0 & 1.9 \\
\hline 20.61 & 4-hydroxyheptanoic acid & 44.2 & 10.1 & 7.8 & 9.5 \\
\hline 28.88 & Diethyl phthalate & - & - & - & 4.4 \\
\hline 29.08 & 2.6-Decadiene-4.5-diol-6-ethyl- & 4.1 & - & - & - \\
\hline 29.90 & Decyl decanoate & 10.2 & - & - & - \\
\hline 31.39 & Gamma-decalactone & 18.0 & - & - & - \\
\hline 31.40 & Gamma-undecalactone & - & - & - & 3.9 \\
\hline & Total & 1519.0 & 1193.0 & 1417.4 & 1325.2 \\
\hline
\end{tabular}

$t_{r}$ : Retention time

\section{Discussion}

Almond cultivars included in this study were investigated in terms of pomological parameters under conventional growing conditions. Gülsoy and Balta (2014) reported an almond selection study included Ferragnes cultivar grown at Aydin city of Turkey. They reported NWE, NLE, KWE, KLE, and K/N as $3.4 \mathrm{~g}, 33.4 \mathrm{~mm}, 1.1 \mathrm{~g}, 25.5 \mathrm{~mm}$, and 32.6, respectively. Parlakçı (2007) performed an adaptation study in Şanlıurfa city of Turkey and included Ferragnes and Ferraduel cultivars. They reported NWE, NLE, 
$\mathrm{KWE}, \mathrm{KLE}$, and $\mathrm{K} / \mathrm{N}$ as $3.3 \mathrm{~g}, 32.6 \mathrm{~mm}, 1.2 \mathrm{~g}, 25.1 \mathrm{~mm}$, and 31.1 for Ferragnes, and $3.7 \mathrm{~g}, 33.4 \mathrm{~mm}, 1.2 \mathrm{~g}, 25.7 \mathrm{~mm}$, and 31.0 for Ferraduel, respectively. Results of these studies were similar each other but slightly lower than this study that probably caused by climatic differences caused by the year and environment.

Only a few previous studies have performed on comparison of chemical differences between organic and conventional almond. Venkatasubramanian (2011) compared commercial food samples of nuts from organic and conventional growing in terms of some sensory characteristics and chemical properties. Even though organic samples were found slightly darker and richer in flavor based on the sensory evaluations of this study, Venkatasubramanian (2011) reported a lighter color for organic almond, and no difference in terms of flavor. The difference of the flavor differences may be caused by fatty acid and volatile aroma compounds compositions. On the other hand, Venkatasubramanian (2011) reported higher protein, but lower fat and moisture content for organic samples when compared with conventional ones. These results are in accordance with total oil results of this current study but in opposite way for protein and moisture content. Relevant differences could be caused by multiple factors including cultivar, environmental differences, post-harvest processing, packaging, storage conditions etc. (Valdés et al., 2015). Yildirim et al. (2016) investigated total oil content of some almond cultivars and reported total oil contents as $61.3 \%$ for Ferragnes and $58.2 \%$ for Ferraduel. Houmy et al. (2016) measured total oil content of Ferragnes and Ferraduel kernel mixture and reported the value as $59.0 \%$ in average.

Sánchez-Bel et al. (2008) compared fatty acid composition of almond kernels sampled from trees fertilized with organic and inorganic fertilizers, and found no difference between the treatments in terms of fatty acid composition. However, current study resulted with significant differences especially in oleic and linoleic acid contents. Yildirim et al. (2016) investigated fatty acid compositions of conventionally grown Ferragnes and Ferraduel cultivars and indicated results in accordance with the results of conventional samples included in this present study. The differences between results of the studies would mainly are caused by growing conditions, and also cultivar difference. Samman et al. (2008) reported an inconsistently varied trend in the fatty acid compositions of edible oil samples of different crops grown organic and conventional including olive, coconut, canola, sesame, and sunflower.

Almonds are one of the most preferred nuts which are a regular part of the human diet since thanks to high nutritional value, and also sensory properties (Sathe et al., 2008; Gonçalves et al., 2018). Consumer preferences are related to nut quality which is associated with attractiveness such as color, size and shape (Kader, 2008), but aroma also play key role in market acceptability (Aceña et al., 2009; Shakerardekani et al., 2013). For this reason, evaluation of aroma compounds is important for determination of final quality of the products. Xiao et al. (2014) analyzed aroma compounds in raw almond samples and detected totally 41 volatile compounds from the groups of alcohols, aldehydes, ketones, and pyrazines. Erten et al. (2017) investigated aromaactive compounds in raw, dry roasted and oil roasted almonds and detected totally 59 aroma compounds including aldehydes, ketones, Nitrogen-containing compounds, Sulfur-containing compounds, acids, furanones, and other unknown compounds. Previously reported studies on volatile compounds in almonds showed that there are a large variety of compounds active in aroma specification of almonds that varies in absence and concentration in depending on various factors (Valdés et al., 2015; Erten, 2016). Erten et al. (2017) also suggested further studies for the identification of 
potentially important unknown aroma compounds in almonds. In furtherance of this suggestion of the authors, most of the aroma-active compounds detected in this present study (all compounds except acetone, butanal, 2-Phenyl-2-propanol, ethylbenzene, and 3-Heptanone) were not reported by previous studies in almonds (Erten, 2016; Kesen et al., 2018).

\section{Conclusions}

This study was conducted to compare organic and conventional almond samples of two different cultivars. Overall physical quality evaluations indicated not a worse even better market quality potential for organic samples of both almond cultivars. Consistent differences were found between fatty acid compositions of organic and conventional samples both of the cultivars. In conclusion, together with various aroma-active compounds detected, organic samples were found richer in total amount and the range of compound diversity.

\section{REFERENCES}

[1] Aceña, L., Vera, L., Guasch, J., Busto, O., Mestres, M. (2010): Comparative study of two extraction techniques to obtain representative aroma extracts for being analysed by gas chromatographyolfactometry: Application to roasted pistachio aroma. - Journal of Chromatography A 1217: 7781-7787.

[2] Anonymous (1993): Me'todos oficiales de ana'lisis; preparacio'n de los e'steres metı'licos (Official methods of analysis; preparation of metallic esters). - Ministerio de Agricultura Pesca y Alimentacio'n; Direccio'n General de Polı'tica Alimentaria (Ministry of Agriculture, Fisheries and Food; General Directorate of Food Policy); Madrid/Spain, 41(2): 135.

[3] Anonymous (2000): Sherlock microbial identification system. - Version 4 MIS operating manual, Newark DE, USA.

[4] Anonymous (2011): Profitability Comparison study of an organic almond orchard versus a conventionally farmed almond orchard in stanislaus county. - California Polytechnic State University, Digital Commons, https:/digitalcommons.calpoly.edu/agbsp/61/ (Available Date: 17.03.2019).

[5] Anonymous (2014): Ilıman iklim meyve türlerinde hasat kriterleri (Harvest criteria in temperate fruits). - Gıda, Tarım ve Hayvancılık Bakanlığı, Meyvecilik Araştırma Enstitüsü (Minisry of Food, Agriculture and Livestock, Fruit Research Institute) http://arastirma.tarim.gov.tr/marem/Belgeler/Yeti\%C5\%9Ftiricilik\%20Bilgileri/Il\%C4\% B1man\%20\%C4\%B0klim\%20Meyvelerinde\%20Hasat\%20Kriterleri.pdf (Available Date: 17.03.2019).

[6] Baymış, M. (2008): Yerli ve Yabancı Bazı Ceviz (Juglans regia L.) Tip ve Çeşitlerinin Kahramanmaraş Ekolojik Şartlarında Performanslarının Belirlenmesi (Assessing of Some Local and Foreign Walnut Type and Varieties (Juglans regia L.) Performances in the Kahramanmaraş Ecological Conditions). - MSc Thesis, Kahramanmaraş Sütçü İmam University, Kahramanmaraş/Turkey.

[7] Bengtsson, J., Ahnstrom, J., Weibull, A. C. (2005): The effects of organic agriculture on biodiversity and abundance: a meta-analysis. - Journal of Applied Ecology 42: 261-269.

[8] Bourn, D., Prescott, J. (2002): A comparison of the nutritional value, sensory qualities, and food safety of organically and conventionally produced foods. - Critical Reviews in Food Science and Nutrition 42(1): 1-34. 
[9] Ekelund, L., Tjarnemo, H. (2004): Consumer preferences for organic vegetables - the case of Sweden. - Acta Horticulturae 655: 121-128.

[10] Erten, E. S. (2016): Characterization of aroma components of raw and roasted almonds and the effect of the oxidative state of the nut on roasted flavor formation. - Phd Dissertation Thesis, University of Illinois at Urbana-Champaign, Illionis/USA.

[11] Erten, E. S., Cadwallader, K. R. (2017): Identification of predominant aroma components of raw, dry roasted and oil roasted almonds. - Food Chemistry 217: 244-253.

[12] FAO (2019): Food and Agriculture Organization, Crop Statistics. http://www.fao.org/faostat/en/\#data/QC (Available Date: 14.04.2019).

[13] Gąstoł, M., Domagała-Świątkiewicz, I., Krośniak, M. (2011): Organic versus conventional-a comparative study on quality and nutritional value of fruit and vegetable juices. - Biological Agriculture \& Horticulture 27(3-4): 310-319.

[14] Gonçalves, B., Oliveira, I., Bacelar, E., Morais, M. C., Aires, A., Cosme, F., VenturaCardoso, J., Anjos, R., Pinto, T. (2018): Aromas and Flavours of Fruits. - In: Generation of Aromas and Flavours DOI: 10.5772/intechopen.72489.

[15] Guichard, S., Bertin, N., Leonardi, C., Gary, C. (2001): Tomato fruit quality in relation to water and carbon fluxes. - Agronomie 21: 385-392.

[16] Gülsoy, E., Balta, F. (2014): Aydın ili Yenipazar, Bozdoğan ve Karacasu ilçeleri badem (Prunus amygdalus Batch) seleksiyonu: pomolojik özellikler (Selection almond (Prunus amygdalus Batch) in Yenipazar, Bozdogan and Karacasu (Aydın): Pomological characteristics). - Akademik Ziraat Dergisi 3(2): 61-68.

[17] Heeb, A., Lundegardh, B., Savage, G., Ericsson, T. (2006): Impact of organic and inorganic fertilizers on yield, taste, and nutritional quality of tomatoes. - Journal of Plant Nutrition and Soil Science 169: 535-541.

[18] Hole, D. G., Perkins, A. J., Wilson, J. D., Alexander, I. H., Grice, P. V., Evans, A. D. (2005): Does organic farming benefit biodiversity. - Biological Conservation 122: 113130.

[19] Houmy, N., Mansouri, F., Benmoumen, A., Elmouden, S., Boujnah, M., Sindic, M., Fauconnier, M. L., Serghini-Caid, H., Elamrani, A. (2016): Characterization of almond kernel oils of five almonds varieties cultivated in Eastern Morocco. - Cahiers Options Méditerranéennes: 1-5.

[20] James, G. S. (1995): Analytical Chemistry of Foods. - Blackie Academic and Professional, London: 117-120.

[21] Kader, A. A. (2008): Impact of nut postharvest handling, de-shelling, drying and storage on quality. - In: Harris, L. J. (ed.) Improving the Safety and Quality of Nuts. Woodhead Publishing, Cambridge/UK.

[22] Kesen, S., Amanpour, A., Selli, S. (2018): Comparative evaluation of the fatty acids and aroma compounds in selected Iranian nut oils. - European Journal of Lipid Science and Technology 120(10): 1800152.

[23] Lester, G. E., Manthey, J. A., Busling, B. S. (2007): Organic vs conventionally grown Rio Red whole grapefruit and juice: comparison of production inputs, market quality, consumer acceptance, and human health-bioactive compounds. - Journal of Agricultural and Food Chemistry 55: 4474-4480.

[24] Magkos, F., Arvaniti, F., Zampelas, A. (2006): Organic food: buying more safety or just peace of mind? a critical review of the literature. - Critical Reviews in Food Science and Nutrition 46: 23-56.

[25] MGM (2019): Resmi İstatistikler, T.C. Tarım ve Orman Bakanlığı, Meteoroloji Genel Müdürlüğü (Cities \& Holiday Resorts, Turkish State Meteorological Service).

[26] Parlakçı, H. (2007): Yabancı Kökenli Değişik Badem Çeşitlerinin Bazı Pomolojik ve Kimyasal Özellikleri ile Bitki Besin Maddesi Kapsamlarının Belirlenmesi (Determination of Some Pomological and Chemical Traits with Nutrient Elements Contents for Some Foreign Originated Different Almond Cultivars). - MSc Thesis, Harran Üniversitesi, Şanlıurfa/Turkey. 
[27] Pretty, J. N., Noble, A. D., Bossio, D., Dixon, J., Hine, R. E., Penning de Vries, F. W. T., Morison, J. I. L. (2006): Resource-conserving agriculture increases yields in developing countries. - Environmental Science and Technology 40: 1114-1119.

[28] Samman, S., Chow, J. W., Foster, M. J., Ahmad, Z. I., Phuyal, J. L., Petocz, P. (2008): Fatty acid composition of edible oils derived from certified organic and conventional agricultural methods. - Food Chemistry 109(3): 670-674.

[29] Sánchez-Bel, P., Egea, I., Martínez-Madrid, M. C., Flores, B., Romojaro, F. (2008): Influence of irrigation and organic/inorganic fertilization on chemical quality of almond (Prunus amygdalus cv. Guara). - Journal of Agricultural and Food Chemistry 56(21): 10056-10062.

[30] Sathe, S., Monaghan, E., Kshiesagar, H., Venkatachalam, M. (2008): Chemical composition of edible nut seeds and its implications in human health. - In: Alsalvar, C., Shahidi, F. (ed.) Tree Nuts Composition, Phytochemicals and Health Effects. Taylor \& Francis Group, Florida/USA.

[31] Shakerardekani, A., Karim, R., Ghazali, H., Chin, N. (2013): Textural, rheological and sensory properties and oxidative stability of nut spreads-a review. - International Journal of Molecular Sciences 14: 4223-4241.

[32] USDA (1970): Official grain standards of the United States. - US Department of Agricultural Consumer and Marketing Service, Grain Division, Revised.

[33] Valdés, A., Beltrán, A., Karabagias, I., Badeka, A., Kontominas, M. G., Garrigós, M. C. (2015): Monitoring the oxidative stability and volatiles in blanched, roasted andfried almonds under normal and accelerated storage conditions by DSC, thermogravimetric analysis and ATR-FTIR. - European Journal of Lipid Science and Technology 117: 1199-1213.

[34] Venkatasubramanian, C. (2011): Nutritional quality and acceptability of organic and conventional foods. - Indian Journal of Science and Technology 4(3): 361-365.

[35] Wood, R., Lenzen, M., Dey, C., Lundie, S. (2006): A comparative study of some environmental impacts of conventional and organic farming in Australia. - Agricultural Systems 89: 324-348.

[36] Xiao, L., Lee, J., Zhang, G., Ebeler, S., Niramani, W., Seiber, J., Mitchell, A. (2014): HSSPME GC/MS characterization of volatiles in raw and dry-roasted almonds (Prunus dulcis). - Food Chemistry 151: 31-39.

[37] Yildirim, A. N., Akinci-Yildirim, F., Şan, B., Sesli, Y. (2016): Total oil content and fatty acid profile of some almond (Amygdalus communis L.) cultivars. - Polish Journal of Food and Nutrition Sciences 66(3): 173-178. 